\title{
Akos Farkas:
}

\section{BURGESS RE JOYCE OR BURGESS DE-JOYCED?}

Anthony Burgess's fascination with James Joyce began as early as the late 1930s when the then six-former's history teacher directed his attention to $A$ Portrait of the Artist as a Young Man. Far from looking for artistic inspiration or aesthetic precepts in the work of an as yet little-known writer, the fifteen year old read the book as an adolescent would, eager to find out about the realities of his own personal life, mundane and spiritual alike. The effect was phenomenal: young John Wilson, as Burgess was known at that time to everybody including himself, was so horrified by the "sermon on hell" in Joyce's novel that he rushed to the nearest confessional to beg for absolution and thus dodge damnation. 1 The last imaginary encounter between master and by that time also masterly disciple was part of a large-scale public event, the centenary celebrations of Joyce's birthday on 2 February, 1982, when the BBC as well as Radio Telefis Eiran broadcast The Blooms of Dublin, a musical version of Ulysses composed by Burgess himself.

In the intervening decades Burgess had come to absorb, assimilate, interpret and reinterpret the Joycean oeuvre to an extent surpassed by probably none of his fellow writers and but few of the Joyce specialists; he could justifiably claim to "have known [Joyce] longer than most of the Joyce professors" (You've Had 371). The numerous end-products of the interpretive process include two monographs (Here Comes Everybody, 1965, [the American edition under the title ReJoyce, 1965],

1 Reading Joyce's passage in question "scared [Burgess] back into the Church" (Coale p. 4); for a more detailed and colourful description of the episode in Burgess's reading life see Little Wilson, 140-41. 
Joysprick, 1973), introductions written to at least two novels by Joyce published anew (Stephen Hero, Ulysses), the editing of Finnegans Wake (Shorter Finnegans Wake, 1966), its translation into the Italian, a television show on Joyce's Dublin years and the above-mentioned musical tribute to Joyce. The sheer bulk of this work, let alone the originality and undeniable validity of many of the insights made by this sympathetic interlocutor, should be enough to impress the professional Joyce scholar - even if the professional Joyce scholar has repeatedly refused to be impressed by the work of Burgess, who in turn has repeatedly disclaimed any pretension to scholarly distinction. ${ }^{2}$

Disavowals of another nature came almost as frequently as books written on, or influenced by, the master. In Joysprick this self-distancing is as yet rather impersonal; here Burgess claims that "Joyce exhausted the possibilities of the interior monologue, as of so many other literary techniques" and then draws the laconic conclusion that "one Ulysses is probably enough" (Joysprick 60). Seventeen years later, in You've Had Your Time the disclaimer is more personal and rings with impatience:

I was dubious about the commission [of writing a book on Joyce later to be entitled Here Comes Everybody], since I saw that its fulfilment might make it too easy for critics of my own work to see me as a satellite of Joyce, which was not true. No post-Joycean novelist can learn anything from him except a certain eccentric scrupulosity in the handling of language, usually interpreted as clumsiness. His literary experiments were meant for himself alone: he drained all the possibilities of formal ingenuity in two massive novels which are not quite novels. After Joyce the novel in England had to start all over again.

(You've Had, 98) ${ }^{3}$

The impatience is even more pronounced when Burgess makes the following comment on the fulfilment of the above-quoted prophecy reviewing the reviews of his novel Napoleon Symphony: "The sacred name was always coming up, as though Joyce were the only fictional innovator" (You've Had, 296).

2 On his relations to the world of academy see his essay "Writer Among Professors" in: Blondes pp. 8-11.

3 A view shared by Kingsley Amis (and the Joyce-critic Matthew Hodgart by whom the former is quoted) who claims that Schoenberg and Joyce were "men of enormous talent, each of whom helped to destroy his art" Cf. Hodgart p. 5. Amis's remark may be a reiteration of T. S. Eliot's opinion according to which Joyce had "destroyed his own future" Quoted by Ellmann p. 542. 
Given the fact that Burgess himself "admits" to having patterned the quasimythological structure of his first novel $A$ Vision of Battlements on Ulysses, and to having "tried to go further than Joyce" at one point in The Worm and the Ring (Little Wilson 363, 369 respectively) it seems strange that he should take to task his own critics for finding correspondences between his own fictional work and that of Joyce. Still in the same autobiography, he chastises his contemporaries for not attempting to bridge the gap between serious literature and entertainment the way Joyce did and recommends Joyce's joyful literary practices for emulation to fellow writers, 4 and elsewhere he suggests that even our sub- and extra-literary existence is being altered by the work of the arch-innovator, because with time "Joyce will flow through the arteries of our ordinary, non-reading, life, for a great writer influences the world whether the world likes it or not " (Here Comes 25-6). Why then, one asks, should Burgess have demurred at his critics insistence that his own fairly extraordinary, reading and, especially, writing existence has also been heavily affected by the same influence?

One possible reason for his objections could be the simple fact that Burgess had indeed not been significantly influenced by Joyce, that however much he might have admired Ulysses, Finnegans Wake and the rest of the Joycean canon, he had managed to 'compartmentalize' himself isolating his reading from his writing capacities. If, after all, having reviewed scores of novels written by contemporaries in his earlier years, he could forswear reading them as a mature writer, in order to avoid being influenced, then why should it be unthinkable that he was also capable of distancing himself from Joyce while he was reading him. Well, whatever mental exploits Burgess, this athlete of the mind, might have been capable of, the hard evidence of the written work, the evidence of his own thirtyone novels are there for anybody to see how much, or how little, he managed to avoid stepping in the footprints of the inimitable master.

Unfortunately - or fortunately - this evidence seems to suggest that, irritating as it may be for Burgess, it is not only in the two above-mentioned novels listed by himself that one can distinctly feel the much-contested influence. With a little exaggeration, one could go so far as to assert that the Joycean influence permeates the whole of Burgess's fictional output and affects every possible aspect of his

4 This is what he says on that head: "The inability to entertain is supposed by some to be an aspect of high seriousness. The trouble with most of my contemporaries, in my view, is that they do not seem to have heard of James Joyce." You've Had p. 74 
creative work. Many of these correspondences have been explored by Burgess's monographers Geoffrey Aggeler and Samuel Coale, and such occasional papers as a 1971 publication by M. J. Friedman or my own contribution to a conference on English studies in 1993.5 What one can cull from these scholarly analyses is that Burgess has very consciously exploited the Joycean technique of mythopoeic structuring - either used in high seriousness to superimpose a pattern suggesting significance on the maze of banality which is our shallow everyday existence6, or, jokingly, in the manner of the mock-heroic epic, to underscore the very same smallness and triteness of our lives through its juxtaposition to the grandiosity of the original epics used7; that Burgess has gone even further than Joyce in experimenting with the musicalisation of prose; that - partly related to this - he has had a predilection for wordplay in general and punning in particular; and that he has been preoccupied with certain themes and motifs - eg. eschatology versus scatology, artistic versus divine creation, independence of will versus loyalty to tradition (especially tradition represented by the Mother Church and the fatherland), and that he has not stopped short of taking for a ride a few of Joyce's hobby horses, such as his theories concerning the biographical background of Shakespeare's Hamlet and King Lear or that the eucharist may evoke associations of cannibalism. 8 In the paper cited above the author of this article even drew up a table of correspondences between the individual chapters in Ulysses and apparently matching novels written by Burgess.

I am sure that with sufficient familiarity with the two authors' respective writings and with some degree of inventiveness anyone could go on adding to this list of borrowings and correspondances. A good further example could be the way Burgess goes one step further than Joyce in that the latter "merely" uses proper names as common nouns where the former turns them into verbs; this is Joyce: "A husky fifenote blew. / Blew. Blue bloom is on the / gold pinnacled hair" (Ulysses 269); "Mr Canvasser Bloom was heard endeavouring to urge, to mollify, to restrain" (Ulysses 434; italics mine); and here is Burgess with his not-soFarkas.

5 Cf. Aggeler, Anthony Burgess and The Comic Art of Anthony Burgess, Friedman, Coale, and

6 Coale, Farkas

7 Aggeler, Anthony Burgess

8 For the latter see my paper "Anthony Burgess and James Joyce." 
hidden reference to Caroline Spurgeon the famous Shakespeare scholar in Notbing Like the Sun: "[beneath the Clopton Bridge flows] the spurgeoning black-eddy?.

Beyond revelling in such curiosa, it is worth mentioning that the delinquent anti-hero Alex in Burgess's A Clockwork Orange may not be a far cry from the arrogantly disrespectful, obscene and sometimes - at least verbally - violent character of Malachi (Buck) Mulligan in Ulysses. The similarity is remarkable between the diction of Stephen Dedalus's friend Buck, wherein the mockingly archaic alternates with the affected childish, and Burgess's character Alex's brilliantly offensive lingo, which also mixes the mock-Jacobean with the quasiinfantile. "Baddybad Stephen lead astray goodygood Malachi," says Mulligan (Ulysses 450) - Alex crunches for breakfast his toast dipped in "jammiwam and eggiweg" (Clockwork Orange, 44)10; Mulligan warns his friend Stephen of Bloom's assumed homosexuality with the words "O, Kinch, thou art in peril. Get thee a breechpad" (Ulysses, 229)11 - "O my brothers" addresses Alex his reader (listener?) whilst narrating his story to "thee and thine" (Clockwork Orange, throughout).

The significance of character-drawing in general goes far beyond the importance of the parallelism Stephen and Alex. Why I find this matter so important is because the difference between Joyce's and Burgess's methods of treating their characters, especially the minor ones, the figures who people the background against which the protagonists play out their leading roles, may well be at the crux of the real difference between the two novelists' literary practices and the two divergent types of aesthetic underlying these practices.

What follows here may strike Joyce's admirers as somewhat heavy-handed, therefore I quote two authorities whose understanding of, and even admiration for, Joyce's work was no less than anybody else's. My first source is an early mentor of Joyce's, the eminent critic of the age William Archer, the second being none other than Anthony Burgess himself. Here is part of a letter Archer wrote to Joyce concerning A Brilliant Career, the drama the young writer had sent Archer for consideration:

9 Quoted by Aggeler, Burges the Artist p. 75

$10 \mathrm{It}$ is worth mentioning that Burgess himself quotes the "baddibad" tag in his Joysprick, p.121, which indicates that this kind of wordplay and the attitude behind it was very much in the back of his mind.

11 This is also quoted by Burgess in Joysprick, p. 41. 
On the whole [...], you seem to me to be deficient as yet in the power of projecting characters so as to seize upon the reader's attention and kindle his imagination.

(Quoted by S. Joyce; My Brother's Keeper, p. 128)

That criticism, of course, was levelled at a very early, and hence immature, piece by Joyce; however, what Burgess has to say about the minor characters in his fiction concerns Joyce the artist as a mature man:

Most lovers of Joyce's pre-Wake work will reluctantly admit that the bulk of the supporting cast of Dubliners in Ulysses have not recovered from the paralysis they are suffering from in the short stories where they first appear. [...] [T] he general effect of the Ulysses background [...] is strangely unvital.

$$
\text { (Joysprick, p. 42) }
$$

Harsh words, one might say, but they may not be as offensive as they seem if we consider that they may not be entirely groundless - telling, say, Mina Douce and Lydia Kennedy or Lyster and Magee in Ulysses apart is indeed no easy task for the non-expert - and, more importantly - that Burgess's unfavourable criticism is based on assumptions about what fiction should accomplish very different from the principles underlying Joyce's practice. The divergent assumptions referred to here are explicated by Burgess himself in a note on his own The Worm and the Ring. $12 \mathrm{He}$ starts off with his own novel and then goes on to compare Joyce's artistic temperament to his own:

The realism overcame the symbolism. This usually happens when the novelist possesses, which Joyce did not, a genuine narrative urge. It requires a perverse devotion to sheer form to hold up action while the symbols sound. The perverseness is most spectacularly visible in 'The Oxen of the Sun' episode of Ulysses, where the meeting of Bloom and Stephen, immensely important to the narration, is occluded by a series of literary parodies which serve the representation of the growth of the embryo in the womb. Could anything be more demented and yet more admirable?

(Little Wilson, 368)

12 A novel whose dreary setting and drab subject matter are in sharp contrast with its Wagnerian mythology. 
The distinction made here is clear: the claims of realism are pitted against those of symbolism; the narrative urge, the urge to tell a straightforward story, is at variance with the urge to bedazzle the reader with the fireworks of stylistic wizardry. The two urges are of course not mutually exclusive as they can be, and indeed often are, present in the same work, but one or the other does tend to control most individual works and, in turn, to dominate the entire work of a given writer. One does not have to be a true Joyce-scholar in order to decide which one of these urges dominates Joyce's work: no doubt it is the "symbolic", rather than the narrative urge. With Burgess it is more difficult to tell. There is little doubt that he is right when, comparing his own fiction to the work of Graham Greene's, he concludes that he "had elected the Joycean way in the sense of deliberate hard words (to check the easy passage of the reader, in the manner of potholes on a road) and occasional ambiguity," as opposed to Greene, who "had made the popular novel of adventure his model" (You've Had, 358). And yet, one can safely say that potholes notwithstanding, most of his work - with the possible exception of $A$ Clockwork Orange, Nothing Like the Sun, Napoleon Symphony, and $M F$ - provides the reader with relatively smooth surfaces to drive along: symbolism here, hard words there, Burgess's novels do possess the kind of psychological realism and, especially, the kind of narrative pull which much of Joyce's work partly or completely lacks. If the above-mentioned experimental novels of Burgess cater for the tastes of an audience grown up on Joyce's artistic experimentation, there is hardly anything in the latter's work which could appeal to a much broader readership ever-eager to follow the exciting yarn spun by the expert story-teller of Burgess's type; in other words, Joyce would never have dreamt of writing a spy story, not even a "spiritual" one like Burgess's Tremour of Intent, a virtual roman a clef such as Earthly Powers or a historical novel in the genre of, say, Any Old Iron. If Burgess is always out to entertain, Joyce - however entertaining people like Burgess himself may find him - could not care less. If Burgess has always had an eye on the best-seller chart,13 Joyce's weak eyes were strongly fixed on his quasi-religious calling as an artist.

Joyce's unwavering loyalty to his art and nothing but his art is amply attested by his work and by his copiously documented biography, so it is only by way of a reminder that I refer to the testimony of $A$ Portrait of the Artist and of the

$13 \mathrm{~W}$ itness his many pieces on, and references to, the topic of "literary trash" (eg. "Prolefeed", "The Boredom of SF", "Tripe?" - in: Blondes). 
biographical monographs James Joyce and My Brother's Keeper, the latter two by professor Richard Ellmann and Joyce's brother Stanislaus, respectively. This is, for example, how Stanislaus Joyce sums up James Joyce's attitude to popularity: "[U]nlike his friend Italo Svevo, who was disappointed at not being a popular success, my brother never cared a rap who read him" (My Brother's Keeper, 54). Unlike Svevo, says Stanislaus Joyce, and very much unlike Burgess, we might add, who is half-embarrassed, but also half-pleased by being a popular success or at least by having the kind of cult following that some of his work (most notably $A$ Clockwork Orange, especially its film version) has generated.14

Here I have only been able to briefly suggest, rather than thoroughly demonstrate, what I see as the major difference between the fictional world of Burgess and that of Joyce, arguably the greatest influence on the former. Endeavouring to fully explore the reasons behind these differences, namely behind the different attitudes to character drawing, the relative importance attached to narrative flow versus formal experimentation and to popular success, would be an even more hopeless task within the confines of this paper. And yet, it would be less than satisfactory to altogether forgo any attempt to at least indicate what these reasons might be. These reasons then appear to be related partly to the different statuses of the two writers and, possibly, to the difference between the aura, the intellectual-spiritual atmosphere of the two ages in which they each worked. Risking the charge of oversimplification, I suggest that while James Joyce could never have grown into what we know him as without the kind of patronage which allowed him to pay little attention to pecuniary considerations, Anthony Burgess is the archetypal professional whose very career as a full-time writer started, according to his own account, at least partly due to financial pressures (Little Wilson, 448). Far be it from the auther of these lines, veteran member of an imaginary Burgess fan-club, to suggest that one of the most significant, if not the most significant, figure of contemporary English fiction was more of a money-making professional than an artist or, conversely, to claim that Joyce was an amateur, but I do believe that the former has always been more willing to recognise the demands of the market place than the latter.

14 The novel The Clockwork Testament or Enderby's End depicts a situation very similar to the one Burgess himself found himself in after the film version of his earlier $A$ Clockwork Orange was released (cf. You've Had p. 285). 
As for the intellectual climate referred to above, the modernist writer regarded his art as something sacred and therefore high above the philistine world of the market place and its pseudo-art (even if this philistine world happened to serve him with his subject matter); the artist of the post-modern aura, however (to resort to this somewhat over-used term), seems to have far fewer inhibitions when it comes to drawing on the devices of sub- or quasi literary genres. And while Joyce is undeniably one of the greatest figures of modernity, Burgess (alongside Vladimir Nabokov or John Barth, who have also freely availed themselves of some of the devices that the verious sub-genres of the paperback novel had to offer) can be seen as a fore-runner of post-modernism: another reason why Burgess has had relatively fewer qualms about being accessible to the uninitiated.

One last qualifying remark does not seem to be out of place. Without the intention of retracting any of the arguments regarding the differences between the nature of Anthony Burgess's work and that of his half-admitted paragon James Joyce, I would like to emphasise that what the former had to learn from the latter and what he emulated thereof in his practice far outweighs all that he ignored or discarded of the Joycean heritage. But that was the subject of an earlier and will possibly be the subject of a later study.

\section{WORKS CITED}

Aggeler, Geoffrey: Anthony Burgess; The Artist as Novelist. Tuscaloosa, Alabama: The University of Alabama Press, 1979.

Aggeler, Geoffrey: "The Comic Art of Anthony Burgess", in: Arizona Quarterly 25, 1969, pp. 234-51.

Coale, Samuel: Anthony Burgess. New York: Frederick Ungar, 1981.

Burgess, Anthony: A Clockwork Orange. London: Heinemann, 1962. New York: Ballantine Books, 1972

Burgess, Anthony: Any Old Iron. London: Hutchinson, 1989.

Burgess, Anthony: Earthly Powers. New York: Avon, 1980.

Burgess, Anthony: Here Comes Everybody. London: Faber and Faber, 1965.

Burgess, Anthony: Joysprick: An Introduction to the Language of James Joyce. London: Deutsch, 1973.

Burgess, Anthony: Little Wilson and Big God. London: Heinemann, 1987.

Burgess, Anthony: MF. London: Cape, 1971.

Burgess, Anthony: Napoleon Symphony. London: Cape, 1974. 
Burgess, Anthony: Nothing Like the Sun. London: Heinemann, 1964.

Burgess, Anthony: ReJoyce. New York: Ballantine Books, 1965.

Burgess, Anthony: Tremour of Intent. London: Heinemann, 1966.

Burgess, Anthony: A Vision of Battlements. London: Sidgwick and Jackson, 1966.

Burgess, Anthony: The Worm and the Ring. London: Heinemann, 1961.

Burgess, Anthony: You've Had Your Time. London: Heinemann, 1990.

Ellmann, Richard: James Joyce. New York: OUP, 1959.

Farkas, Akos: "Anthony Burgess and James Joyce; Allusion Technique or Entertainment", paper presented at the first, 1993, national conference of HUSSE in Debrecen, Hungary. Pending publication.

Friedman, Melvin J: "Anthony Burgess and James Joyce: A Literary Confrontation", Literary Criticism 9, 1971, 71-83.

Hodgart, Matthhew: James Joyce: A Student's Guide. London:Routledge, 1978.

Joyce, James: A Portrait of the Artist as a Young Man. in: Levin, Harry (ed.) The Portable James Joyce. New York: Viking, Penguin, 1976.

Joyce, James: Ulysses. London: Minerva, 1992. Introduction by Anthony Burgess. Joyce, Stanislaus: My Brother's Keeper. London: Faber and Faber, 1958. 